\title{
Nutrient support via fertigation with domestic effluent and growth \\ of cotton
}

\section{Aporte de nutrientes via fertirrigação com efluente doméstico e crescimento do algodoeiro}

\author{
Francisco Gonçalo Filho'; Miguel Ferreira Neto ${ }^{2}$; Cleyton dos Santos Fernandes ${ }^{3}$; \\ Francisco Vanies da Silva Sá4*; Nildo da Silva Dias²; José Francismar de \\ Medeiros $^{2}$
}

\section{Highlights:}

Treated domestic effluent is an important water and nutritional source for cotton; Treated domestic effluent meets $100 \%$ of the cotton $\mathrm{Mg}, \mathrm{Mn}$ and $\mathrm{Zn}$ requirements; There is residual effect of treated domestic effluent for the second crop cycle.

\begin{abstract}
Because of climatic problems in the Brazilian semi-arid region, it is of fundamental importance to seek a culture that considers water scarcity and available natural resources. Thus, a randomized block design, with subdivided plots and six replications, was carried out in the experimental area of the treatment and wastewater reuse station of the Milagres Settlement, Apodi, Brazil, with the objective of evaluating cultivation of herbaceous cotton (Gossipyum hirsutum) fertigated with domestic sewage treated in a semi-arid environment. Two cultivation cycles were carried out, and the cotton plants were fed with three different solutions containing treated domestic sewage (TDE) plus supply water (PSW), to supply the crop evapotranspiration (ETc) (100\% PSW - control, 50\% PSW + 50\% TDE and 100\% TDE), with and without phosphate fertilization in pre-planting. The contribution of nutrients to the soil and plant growth were analyzed. The results indicated that the wastewater presents potential fertilizer, reaching to the soil amounts of some nutrients exceeding the cotton's needs, when $100 \%$ of the ETc was supplied via fertigation with domestic effluent, resulting in an increase in the growth rates of the plants. There was no interaction between the percentages of wastewater and phosphate fertilization in pre-planting. Phosphorus alone promoted significant variation only in the first cycle, indicating that there is a residual fertigation effect with domestic effluent on the nutrient supply.
\end{abstract}

Key words: Gossipyum hirsutum. Plant nutrition. Irrigation. Water reuse.

1 Dr., Bolsista de Desenvolvimento Regional, Universidade Federal Rural do Semi-Árido, UFERSA, Campus Mossoró, Mossoró, RN, Brasil. E-mail: goncalofilho.rn@gmail.com

2 Profs. Drs., Centro de Ciências Agrárias, UFERSA, Campus Mossoró, Mossoró, RN, Brasil. E-mail: miguel@ufersa.edu.br; nildo@ufersa.edu.br; jfmedeir@ufersa.edu.br

3 Discente do Curso de Doutorado do Programa de Pós-Graduação em Fitotecnia, UFERSA, Campus Mossoró, Mossoró, RN, Brasil. E-mail: cleyton1959@hotmail.com

4 Dr., Bolsista do Programa Nacional de Pós-Doutorado, UFERSA, Campus Mossoró, Mossoró, RN, Brasil. E-mail: vanies_ agronomia@hotmail.com

* Author for correspondence 


\section{Resumo}

Devido aos problemas climáticos no semiárido brasileiro é de fundamental importância que se busque uma cultura que considere a escassez hídrica e os recursos naturais disponíveis. Deste modo, um experimento em delineamento de blocos ao acaso, com parcelas subdivididas e seis repetições foi conduzido na área experimental da estação de tratamento e reuso de águas residuais do Assentamento Milagres, Apodi - RN, com o objetivo de avaliar o cultivo de algodoeiro herbáceo (Gossipyum hirsutum) fertirrigado com efluente de esgoto doméstico tratado em ambiente semiárido. Foram realizados dois ciclos de cultivo e as plantas de algodão foram nutridas com três diferentes soluções contendo efluente de esgoto doméstico tratado (PSW) + água de abastecimento (TDE) para suprir a evapotranspiração da cultura (ETc) (100\% PSW - control, 50\% PSW + 50\% TDE and 100\% TDE) com e sem adubação fosfatada em pré-plantio. Analisou-se o aporte de nutrientes ao solo e o crescimento das plantas. Os resultados indicaram que o efluente doméstico tratado apresenta potencial fertilizante, chegando a aportar ao solo quantidades de alguns nutrientes superiores a necessidade do algodoeiro, quando $100 \%$ da ETc foi suprida via fertirrigação com efluente doméstico, resultando em incremento das taxas de crescimento das plantas. Não se constatou interação entre as porcentagens de efluente doméstico tratado e a adubação fosfatada em pré-plantio. $O$ fósforo isoladamente promoveu variação significativa apenas no primeiro ciclo, indicando que há um efeito residual da fertirrigação com efluente doméstico no aporte do nutriente.

Palavras-chave: Gossipyum hirsutum. Nutrição de plantas. Irrigação. Reuso de água.

\section{Introduction}

In semi-arid regions, such as Northeast Brazil, there is water scarcity, triggered by the low levels of rainfall and high rates of evapotranspiration, which result in the lack of potable quality water for human consumption and other activities, such as agriculture, because in these regions the success of agriculture greatly depends on the practice of irrigation. In this scenario, it is necessary to provide alternatives aimed at solving such a major problem.

A rational alternative, from the social, economic and environmental points of view, would be the reuse of water from domestic activities for agricultural purposes, because large volumes of wastewater are produced every day and released in water bodies and in the soil, often without receiving any treatment (Sousa et al., 2012). In this context, the reuse of water, if adequately performed, is characterized as a conservational practice and its application allows obtaining numerous benefits combined, including the improvement in the nutritional status of plants and in soil fertility (Cunha, Oliveira, Ferreira, Milhardes, \& Silva, 2011).
Countries such as Egypt, Australia, Saudi Arabia, Tunisia, Chile and Israel have used treated domestic effluents in agriculture, but in Brazil it is not a common practice, and the effects of its application on the soil and the benefits for plants are not fully known, so further investigations are needed (Silva et al., 2011; Ribeiro et al., 2012).

Thus, the use of treated domestic effluents plays a fundamental role in the planning and sustainable management of water resources, as it allows the sources of potable quality water to be used for public supply and other priority uses (Lunardi \& Rabaiolli, 2013). In addition, it constitutes an alternative for the control of the pollution of the water soil atmosphere system, supply and recycling of nutrients that are essential for several crops and consequent increase in agricultural production (Costa et al., 2014). However, for this to become a feasible practice, it is necessary to perfect the techniques of treatment, application and management of these effluents (Bertoncini, 2008; Condé, Homem, Almeida, \& Santiago, 2012). 
At the Apodi Plateau, in the state of Rio Grande do Norte, there is a predominance of soils with calcareous formation, which are usually alkaline and poor in phosphorus, with imbalanced cationic ratios and, additionally, the cationic composition of macronutrients is not favorable in terms of magnesium and/or potassium (Holanda et al., 2017). In sites like this, the requirement of phosphorus by crops can be fully met using domestic effluents because these sources of water usually contain a high concentration of this nutrient, as a result of the use of detergents and other phosphorus-rich substances in domestic activities, such as dish washing.

Given the above, the objective was to evaluate the supply of nutrients through fertigation with treated domestic effluent in several percentages in substitution for public supply water to meet the water requirement and growth of the herbaceous cotton cultivar BRS 335, under fertigation and pre-planting phosphate fertilization, using daily calculations obtained in different periods of crop development, in two cycles.

\section{Material and Methods}

The experiment was carried out in two agricultural cycles, in the years 2016 and 2017, in the Milagres Settlement Project, in the municipality of Apodi, Rio Grande do Norte, Brazil, at geographic coordinates $5^{\circ} 35^{\prime} 18.82$ ' S latitude, $37^{\circ} 54^{\prime} 08.48$ " W longitude and at altitude $109 \mathrm{~m}$.

The area has a flatrelief with dominant slope ofless than $2 \%$, and the soils covering it are CAMBISSOLOS HÁPLICOS Ta Eutróficos (Inceptisols), according to the Brazilian Soil Classification System (Santos et al., 2013). According to Diniz and Pereira (2015), the predominant climate of the region is equatorial zone tropical, with three subtypes - mild semi-arid, medium semi-arid and strong semi-arid.

The experiment was installed in a split-plot randomized block design, with three percentages of treated domestic effluent (TDE) applied through fertigation to meet the water requirement of the crop (ETc) in substitution for public supply water (PSW) (ETc replaced with 100\% PSW - $\mathrm{T}_{1}, 50 \% \mathrm{PSW}+$ $50 \% \mathrm{TDE}-\mathrm{T}_{2}$ and $100 \% \mathrm{TDE}-\mathrm{T}_{3}$ ) in the plots, and phosphate fertilization (with and without phosphate fertilization at pre-planting) in the subplots, with six replicates, in a total of 36 experimental units, which together corresponded to $979.2 \mathrm{~m}^{2}$. Each experimental unit comprised four rows, $8 \mathrm{~m}$ long each, at double spacing $(1.10 \mathrm{~m} \times 0.5 \mathrm{~m} \times 0.1$ $\mathrm{m})$, with a total area of $27.2 \mathrm{~m}^{2}(3.2 \mathrm{~m} \times 8.5 \mathrm{~m})$, considering as usable area $7.0 \mathrm{~m}$ of the two central rows, disregarding $0.75 \mathrm{~m}$ on each end.

Tillage in the area was performed by plowing and harrowing, followed by furrowing. Soil chemical and physical characterization (Tables 1 and 2) was carried out in the Laboratory of Soil, Water and Plants of the Federal Rural University of the Semi-Arid Region - UFERSA, according to the methodology described by Empresa Brasileira de Pesquisa Agropecuária [EMBRAPA] (2011). These data were then used to stipulate the phosphate fertilization according to A. C. Ribeiro, Guimarães and Alvarez (1999), for obtaining high yield of the crop. The fertilizer was added to the soil and incorporated to the first $0.05 \mathrm{~m}$ of depth. 
Table 1

Chemical characteristics of the soil of the experimental area

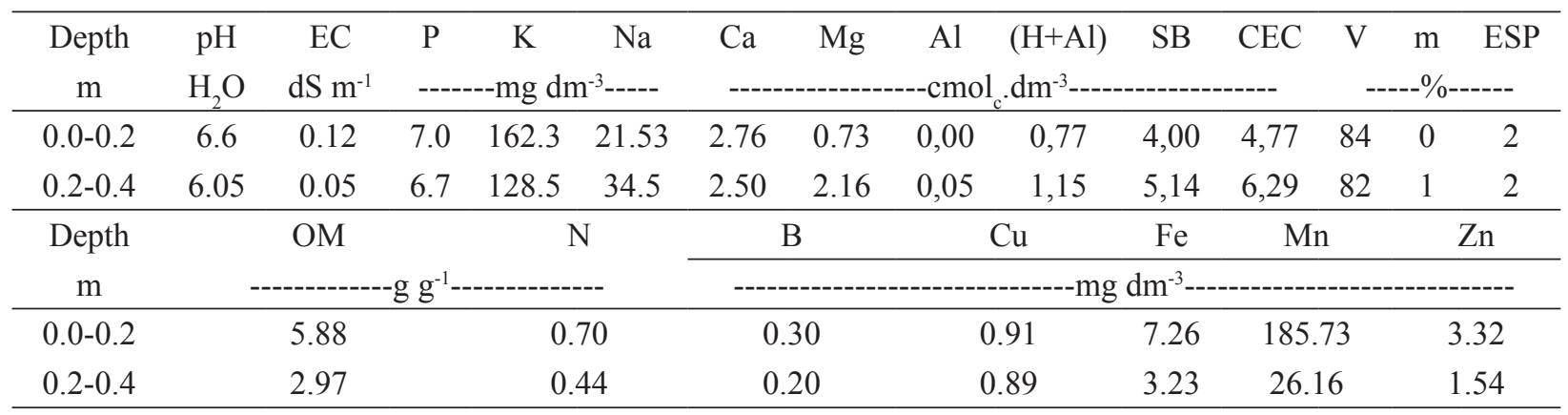

pH $\left(\mathrm{H}_{2} \mathrm{O}\right)$ : Hydrogen potential in water; EC: electrical conductivity; P: Phosphorus; K: Potassium; Na: Sodium; Ca: Calcium; Mg: Magnesium; Al: Aluminum; H + Al: Potential acidity; SB: Sum of bases; CEC: Cation exchange capacity; V: Base saturation; m: Aluminum saturation; ESP: Exchangeable sodium percentage; OM: Organic matter; N: Nitrogen; B: Boron; Cu: Copper; Fe: Iron; Mn: Manganese; Zn: Zinc.

Table 2

Physical characteristics of the soil of the experimental area

\begin{tabular}{|c|c|c|c|c|c|c|c|c|c|c|c|c|c|}
\hline \multirow{3}{*}{$\begin{array}{l}\text { Depth } \\
\text { m }\end{array}$} & \multirow[t]{2}{*}{ Sand } & \multirow[t]{2}{*}{ Silt } & \multirow[t]{2}{*}{ Clay } & \multirow{2}{*}{$\begin{array}{c}\text { Textural } \\
\text { classification }\end{array}$} & \multirow[t]{2}{*}{$\mathrm{Pd}$} & \multirow[t]{2}{*}{$\mathrm{Bd}$} & \multirow[t]{2}{*}{$\mathrm{Tp}$} & \multicolumn{3}{|c|}{$\begin{array}{l}\text { Moisture in ten- } \\
\text { sions }(\mathrm{KPa})\end{array}$} & \multicolumn{3}{|c|}{ Water availability } \\
\hline & & & & & & & & 10 & 33 & 500 & TWA & TWC & AWC \\
\hline & \multicolumn{3}{|c|}{------kg.kg ${ }^{-1}------$} & & \multicolumn{2}{|c|}{$\mathrm{kg} \mathrm{dm}^{-3}$} & $\%$ & \multicolumn{3}{|c|}{------ \% ------- } & $\mathrm{mm} \mathrm{cm}^{-1}$ & $\mathrm{~mm}$ & $\mathrm{Mm}$ \\
\hline $0.0-0.2$ & 0.820 & 0.078 & 0.102 & Loamy sand & 2.77 & 1.68 & 36.6 & 11.85 & 6.74 & 3.84 & 1.34 & 26.85 & 13.42 \\
\hline $0.2-0.4$ & 0.608 & 0.070 & 0.322 & Sand clay loam & 2.84 & 1.73 & 38.8 & 11.60 & 8.86 & 6.23 & 0.43 & 8.78 & 4.39 \\
\hline
\end{tabular}

Pd: Particle density; BD: Bulk density; TP: Total porosity; TWA: Total water availability; TWC: total water storage capacity; AWC: Actual water storage capacity.

For irrigation of the experimental area, waters from the primary treatment system and from the tubular well $(150 \mathrm{~m}$ deep) that supplies the community were stored in two different tanks, from which they were pressurized by two independent $1.5 \mathrm{hp}$ electric pump sets, always working at the same pressure.

An irrigation system called "modified bubbler" was used. This system was designed to be resistant to clogging, reduce energy consumption and work at low pressures (Hao, Li, Wang, \& Li, 2017). The system was installed using microtube emitters, with internal diameter of $3 \mathrm{~mm}$, in order to avoid clogging by suspended particles present in the effluent, hence not requiring sophisticated filtering systems.
The irrigation system was composed of 50 and $32 \mathrm{~mm}$ diameter main and sub-mains, made of $\mathrm{PVC}$, and $16 \mathrm{~mm}$ diameter polyethylene lateral lines, spaced at $3.2 \mathrm{~m}$. The microtube emitters were connected to these lines to irrigate the two leveled furrows with length of $2 \mathrm{~m}$.

Initially, one irrigation was performed with public supply water in all treatments, in order to leave them close to field capacity. Then, the cotton cultivar BRS 335 was planted, by placing 10 seeds per linear meter at $3 \mathrm{~cm}$ depth and alternating between the sides of the irrigation furrow, in double rows $(1.10 \mathrm{~m} \times 0.5 \mathrm{~m} \times 0.1 \mathrm{~m})$, totaling a population of 125,000 plants ha ${ }^{-1}$. At 10 days after planting (DAP), a period during which germination stabilized, the treatments began to be applied. 
Irrigations after planting were carried out on the basis of crop evapotranspiration (ETc), determined according to the reference evapotranspiration (ETo) calculated by the Penman-Monteith equation, parameterized by Food and Agriculture Organization of the United Nations - FAO (Allen, Pereira, Raes, \& Smith, 2006). The data were obtained at the weather station of the National Institute of Meteorology - INMET (Apodi - RN) and the crop coefficient was obtained according to the FAO 56 Manual (Allen et al., 2006) (Equation $1)$, with irrigation interval of 2 days. At the end of each day, the climatic data necessary to feed the irrigation spreadsheet were collected and used to determine the irrigation depth of the next day. When $60 \%$ of the cotton bolls were open, irrigation was suspended.

$$
\mathrm{ETc}=\mathrm{ETo} \times \mathrm{Kc}
$$

(Equation 1)

Where: $\mathrm{ETc}=$ Crop evapotranspiration $(\mathrm{mm})$;

$\mathrm{Kc}=$ crop coefficient (unitless).

To calculate the irrigation depth, for an interval of 2 days, the following expression was used:

$$
\mathrm{L}=(\mathrm{ETc} \times 2) / \mathrm{f}
$$

Where: $\mathrm{L}$ is the irrigation depth $(\mathrm{mm})$;

ETc is the average crop evapotranspiration $(\mathrm{mm})$; and

$\mathrm{f}$ is the application efficiency (unitless, considered equal to 0.85 , value of the distribution uniformity coefficient - DUC).

Agronomic data and irrigation parameters are presented in Table 3.

Table 3

Agronomic data and irrigation parameters during the cotton cultivation cycles of 2016 and 2017

\begin{tabular}{lcc}
\hline Variables & 2016 & 2017 \\
\hline Planting date & $07 / 10 / 2016$ & $11 / 08 / 2017$ \\
Planting density & $12-13$ plants $\mathrm{m}^{-2}$ & $12-13$ plants $^{-2}$ \\
Planting fertilization* & $100 \mathrm{~kg}$ of Triple superphosphate $\mathrm{ha}^{-1}$ & $100 \mathrm{~kg}$ of Triple superphosphate ha ${ }^{-1}$ \\
Fertigation beginning & $17 / 10 / 2017(10 \mathrm{DAP})$ & $21 / 08 / 2017$ (10 DAP) \\
Last irrigation & $11 / 01 / 2017(97 \mathrm{DAP})$ & $21 / 11 / 2017(103 \mathrm{DAP})$ \\
Irrigation water & $709,7 \mathrm{~mm}$ & $759,1 \mathrm{~mm}$ \\
Total rainfall & $0,0 \mathrm{~mm}$ & $0,0 \mathrm{~mm}$ \\
Harvest date & $27 / 01 / 2017$ & $08 / 12 / 2017$ \\
Length of cultivation cycle & 113 DAP & $120 \mathrm{DAP}$ \\
\hline
\end{tabular}

*In the subplots with this treatment; DAP - Days after planting.

Weeds were controlled through the mechanical method, with a hoe, twice - once at 15 and the second time at 25 days after germination (DAG). From then on, weeding was no longer necessary, because the shading caused by the plants inhibited the emergence of spontaneous plants. Pests were sampled every week, and when populations reached the level requiring control, products registered for the pest were applied.

For monitoring and evaluating the quality of the effluent and public supply water, once a month samples were collected between 10:00 and 12:00 $\mathrm{h}$ for analysis. After collection, the samples were placed in an appropriate container, kept at low 
temperature with ice and immediately transported to the laboratory for analysis procedures, where their chemical, physical and microbiological characteristics were evaluated. These analyses were carried out in the Laboratory of Soil, Water and Plant Analysis (LASAP), Laboratory of Animal Products Inspection (LISPOA) and Laboratory Sanitation, at UFERSA, and in the Laboratory of Physical-Chemical Diagnosis of the State University of Rio Grande do Norte (UERN), following the recommendations described in the "Standard Methods for the Examination of Water and Wastewater" of the American Public Health Association - APHA (Rice, Baird, \& Clesceri, 2012).

The calculation of the nutrient supply took consideration of the concentrations of nutrients determined in the effluent and in the public supply water, on the basis of the water depth applied through irrigation, and the amount of nutrients added to the soil in each cycle was obtained by multiplying the concentrations of nutrients by the total water depth applied.

Plant growth was evaluated on the basis of the absolute growth rate of total shoot dry biomass $\left(\mathrm{AGR}_{\mathrm{TB}}\right)$ and the relative growth rate of total biomass $\left(\mathrm{RGR}_{\mathrm{TB}}\right)$, which were calculated using the means of data from three plants per subplot. Biomass measurements were performed at 22, 36, 50, 64, 78 and $92 \mathrm{DAG}$, during the first cultivation cycle, and at 16, 28, 42, 56, 70 and 84 DAG in the second cycle.
$\mathrm{AGR}_{\mathrm{TB}}$ was determined according to Equation 3 (Fernandes, 2002).

$$
\mathrm{AGR}_{\mathrm{TB}}=\mathrm{SDB}_{2}-\mathrm{SDB}_{1} /\left(\mathrm{t}_{2}-\mathrm{t}_{1}\right) \quad \text { (Equation 3) }
$$

Where: $\mathrm{AGR}_{\mathrm{TB}}=$ Absolute growth rate in $\mathrm{SDB}$ $\left(\mathrm{g} \cdot\right.$ day $\left.^{-1}\right)$;

$\mathrm{SDB}_{1}=$ Shoot dry biomass relative to time $\mathrm{t}_{1}(\mathrm{~g})$;

$\mathrm{SDB}_{2}=$ Shoot dry biomass relative to time $\mathrm{t}_{2}(\mathrm{~g})$ and;

$\mathrm{t}_{2}-\mathrm{t}_{1}=$ Time interval between two consecutive readings (days).

$\mathrm{RGR}_{\mathrm{TB}}$ was calculated using Equation 4.

$\left.\mathrm{RGR}_{\mathrm{TB}}=\ln \left(\mathrm{STB}_{2}-\operatorname{lnSTB}\right)_{1}\right) /\left(\mathrm{t}_{2}-\mathrm{t}_{1}\right)\left(\mathrm{g} \cdot \mathrm{g}^{-1} \cdot \mathrm{day}^{-1}\right)$

(Equation 4)

Where: $\ln =$ Natural logarithm;

$\mathrm{STB}_{1}=$ Shoot total biomass relative to $\mathrm{t}_{1}(\mathrm{~cm})$.

$\mathrm{STB}_{2}=$ Shoot total biomass relative to $\mathrm{t}_{2}(\mathrm{~cm})$ and;

$\mathrm{t}_{2}-\mathrm{t}_{1}=$ Time interval between two consecutive readings (days).

The data of the growth variables were subjected to analysis of variance by the F-test at the 5\% probability level, and the means were compared by the Tukey test at the 5\% probability level, using the statistical program Sisvar (Ferreira, 2011).

\section{Results and Discussion}

Supply of nutrients via treated domestic effluent

The water depths applied in the two cultivation cycles of herbaceous cotton, in the germination and post-germination periods, are presented in Table 4. In total, 709.7 and $792.6 \mathrm{~mm}$ were required in 2016 and 2017, respectively, for the crop to complete its cycle. 
Table 4

Water depths applied to replace crop evapotranspiration in the two cultivation cycles, with stratification of the part of the water depth supplied with treated domestic sewage effluent

\begin{tabular}{|c|c|c|c|c|c|}
\hline \multirow[b]{4}{*}{ Treatments $^{3}$} & \multicolumn{2}{|c|}{ Period $1(\mathrm{P} 1)$} & \multicolumn{2}{|c|}{ Period $2(\mathrm{P} 2)$} & \\
\hline & \multicolumn{4}{|c|}{ Water type } & \\
\hline & PSW & TDE & PSW & TDE & \\
\hline & \multicolumn{4}{|c|}{-------------- Applied water (mm) - 2016 cycle -------------- } & Total $(\mathrm{mm})$ \\
\hline $\mathrm{T}_{1}$ & 41.62 & 0.00 & 688.04 & 0.00 & 709.7 \\
\hline $\mathrm{T}_{2}$ & 41.62 & 0.00 & 334.0 & 334.0 & 709.7 \\
\hline \multirow[t]{2}{*}{$\mathrm{T}_{3}$} & 41.62 & 0.00 & 0.00 & 688.0 & 709.7 \\
\hline & \multicolumn{4}{|c|}{------------- Applied water (mm) - 2017 cycle ------------- } & Total $(\mathrm{mm})$ \\
\hline $\mathrm{T}_{1}$ & 33.50 & 0.00 & 759.1 & 0.00 & 792.6 \\
\hline $\mathrm{T}_{2}$ & 33.50 & 0.00 & 379.5 & 379.5 & 792.6 \\
\hline $\mathrm{T}_{3}$ & 33.50 & 0.00 & 0.00 & 759.1 & 792.6 \\
\hline
\end{tabular}

P1 - Period from planting to stabilization of germination (10 days after planting); P2 - Period from stabilization of germination to the suspension of irrigation; PSW - Public supply water; TDE - Treated domestic effluent.

Table 5 contains the descriptive statistics for the results of the physicochemical and biological characteristics of the TDE samples collected during the monthly monitoring of water quality during the study.
From the nutrient concentrations determined for the TDE and PSW, the quantities of nutrients added to the soil by fertigation were estimated on the basis of the water depths applied through irrigation in the two cultivation cycles (Table 6). 


\section{Table 5}

Physicochemical and biological characteristics of the treated domestic sewage effluent (TDE) and public supply water (PSW) used in the experiment

\begin{tabular}{|c|c|c|c|c|}
\hline Characteristics & TDE* & $\mathrm{Sd}$ & PSW & $\mathrm{Sd}$ \\
\hline $\mathrm{pH}\left(\mathrm{H}_{2} \mathrm{O}\right)$ & 7.40 & \pm 0.43 & 6.84 & \pm 0.17 \\
\hline $\mathrm{EC}\left(\mathrm{ds} \mathrm{m^{-1 }}\right)$ & 1.09 & \pm 0.15 & 0.09 & \pm 0.01 \\
\hline $\mathrm{K}\left(\mathrm{mg} \mathrm{L}^{-1}\right)$ & 27.37 & \pm 3.91 & 9.38 & \pm 2.74 \\
\hline $\mathrm{Na}\left(\mathrm{mg} \mathrm{L}^{-1}\right)$ & 74.95 & \pm 12.42 & 3.91 & \pm 0.23 \\
\hline $\mathrm{Ca}\left(\mathrm{mg} \mathrm{L}^{-1}\right)$ & 18.44 & \pm 1.80 & 11.14 & \pm 7.29 \\
\hline $\operatorname{Mg}\left(\mathrm{mg} \mathrm{L}^{-1}\right)$ & 23.33 & \pm 13.49 & 8.14 & \pm 4.37 \\
\hline $\mathrm{Cl}^{-}\left(\mathrm{mg} \mathrm{L}^{-1}\right)$ & 125.85 & \pm 39.35 & 31.55 & \pm 2.13 \\
\hline $\mathrm{CO}_{3}^{2}\left(\mathrm{mg} \mathrm{L}^{-1}\right)$ & 0.00 & \pm 0.00 & 0.00 & \pm 0.00 \\
\hline $\mathrm{HCO}_{3}^{-}\left(\mathrm{mg} \mathrm{L}^{-1}\right)$ & 408.70 & \pm 31.11 & 29.28 & \pm 1.83 \\
\hline $\operatorname{SAR}\left(\mathrm{mg} \mathrm{L}^{-1}\right)$ & 2.80 & \pm 0.48 & 0.21 & \pm 0.10 \\
\hline $\mathrm{P}\left(\left(\mathrm{mg} \mathrm{L}^{-1}\right)\right.$ & 7.82 & \pm 0.95 & 0.57 & \pm 0.12 \\
\hline $\mathrm{N}-\mathrm{NH}_{4}\left(\mathrm{mg} \mathrm{L}^{-1}\right)$ & 29.91 & \pm 9.29 & 0.56 & \pm 0.98 \\
\hline $\mathrm{N}-\mathrm{NO}_{3}\left(\mathrm{mg} \mathrm{L}^{-1}\right)$ & 14.58 & \pm 18.73 & 0.02 & \pm 0.03 \\
\hline Suspended solids $\left(\mathrm{mg} \mathrm{L}^{-1}\right)$ & 33.00 & \pm 11.00 & 0.00 & \pm 0.00 \\
\hline Dissolved solids $\left(\mathrm{mg} \mathrm{L}^{-1}\right)$ & 389.00 & \pm 39.00 & 53.00 & \pm 3.00 \\
\hline $\mathrm{OGC}\left(\mathrm{mg} \mathrm{L}^{-1}\right)$ & 18.1 & \pm 3.32 & - & - \\
\hline $\mathrm{BOD}\left(\mathrm{mg} \mathrm{L}^{-1}\right)$ & 18.75 & \pm 10.90 & - & - \\
\hline $\mathrm{COD}\left(\mathrm{mg} \mathrm{L}^{-1}\right)$ & 94.00 & \pm 10.80 & - & - \\
\hline Total coliforms (NMP $100 \mathrm{~mL}^{-1}$ ) & 1100.00 & \pm 169.71 & 0.00 & \pm 0.00 \\
\hline Thermotolerant coliforms (NMP $100 \mathrm{~mL}^{-1}$ ) & 290.00 & \pm 44.74 & 0.00 & \pm 0.00 \\
\hline $\mathrm{Cu}\left(\mathrm{mg} \mathrm{L}^{-1}\right)$ & 0.08 & \pm 0.005 & 0.02 & \pm 0.01 \\
\hline $\operatorname{Mn}\left(\mathrm{mg} \mathrm{L}^{-1}\right)$ & 0.08 & \pm 0.009 & 0.06 & \pm 0.01 \\
\hline $\mathrm{Fe}\left(\mathrm{mg} \mathrm{L}^{-1}\right)$ & 0.24 & \pm 0.018 & 0.23 & \pm 0.03 \\
\hline $\mathrm{Zn}\left(\mathrm{mg} \mathrm{L}^{-1}\right)$ & 0.05 & \pm 0.041 & 0.15 & \pm 0.04 \\
\hline $\mathrm{Cr}\left(\mathrm{mg} \mathrm{L}^{-1}\right)$ & 0.00 & \pm 0.00 & 0.00 & \pm 0.00 \\
\hline $\mathrm{Ni}\left(\mathrm{mg} \mathrm{L}^{-1}\right)$ & 0.00 & \pm 0.00 & 0.00 & \pm 0.00 \\
\hline $\mathrm{Cd}\left(\mathrm{mg} \mathrm{L}^{-1}\right)$ & 0.00 & \pm 0.00 & 0.00 & \pm 0.00 \\
\hline $\mathrm{Pb}\left(\mathrm{mg} \mathrm{L}^{-1}\right)$ & 0.00 & \pm 0.00 & 0.00 & \pm 0.00 \\
\hline
\end{tabular}

*Mean values and standard deviation (SD);

PSW - Public supply water; TDE - Treated domestic effluent; $\mathrm{pH}\left(\mathrm{H}_{2} \mathrm{O}\right)$ : Hydrogen potential in water; EC: Electrical conductivity; P: Phosphorus; K: Potassium; Na: Sodium; Ca: Calcium; Mg: Magnesium; $\mathrm{Cl}:$ Chlorine; $\mathrm{CO}_{3}^{2-}:$ Carbonate; $\mathrm{HCO}_{3}:$ : Bicarbonate; SAR: Sodium adsorption ratio; P: Phosphorus; $\mathrm{NH}_{4}^{+}-\mathrm{N}$ : Ammoniacal nitrogen; $\mathrm{NO}_{3}^{-}{ }^{-} \mathrm{N}$ : Nitric nitrogen; OGC: Oil and grease content; BOD: Biochemical oxygen demand; COD: Chemical oxygen demand; Cu: Copper; Mn: Manganese; Fe: Iron; Zn: Zinc; Cr: Chromium; Ni: Nickel; Cd: Cadmium; Pb: Lead. 
The percentages of nutrients supplied in relation to the quantities required by herbaceous cotton cultivar BRS 335, for a production of 5 ton ha1 , are systematized in Table 7 . When $50 \%$ PSW + $50 \%$ TDE was used in the irrigation of cotton after stabilization of germination, the amounts added to the soil were larger than the requirements for $\mathrm{Mg}$, $\mathrm{Mn}, \mathrm{Zn}$ and $\mathrm{Cu}$ for this cultivar, 50\% higher than the requirements for $\mathrm{P}, \mathrm{K}, \mathrm{Ca}$ and $\mathrm{Fe}$, and $45 \%$ higher than for the nutritional requirements for $\mathrm{N}$ in the two cultivation cycles.

Also regarding Table 7, it was found that the quantities of nutrients added to the soil in $\mathrm{T}_{3}$ are greater than the crop requirements for $\mathrm{P}, \mathrm{Mg}, \mathrm{Mn}$, $\mathrm{Zn}$ and $\mathrm{Cu}$ in the two cycles of cultivation, besides providing quantities exceeding $90 \%$ of the needs for $\mathrm{N}$ and $\mathrm{Ca}$, greater than $70 \%$ of the requirements for $\mathrm{K}$ and greater than $50 \%$ of the requirements for $\mathrm{Fe}$, in the two cultivation cycles.

Table 6

Nutrient supply via treated domestic effluent

\begin{tabular}{|c|c|c|c|c|c|c|c|c|c|c|c|c|c|}
\hline \multirow{3}{*}{ Treatments } & \multicolumn{8}{|c|}{ Macronutrients } & \multicolumn{5}{|c|}{ Micronutrients } \\
\hline & \multicolumn{13}{|c|}{2016 cycle } \\
\hline & $\mathrm{N}^{-\mathrm{NH}_{4}^{+}}$ & $\mathrm{N}-\mathrm{NO}_{3}^{-}$ & N Total & $\mathrm{P}$ & $\mathrm{K}$ & $\mathrm{Ca}$ & $\mathrm{Mg}$ & $\mathrm{Fe}$ & $\mathrm{Mn}$ & $\mathrm{Zn}$ & $\mathrm{Cu}$ & $\mathrm{Na}$ & $\mathrm{Cl}$ \\
\hline $\mathrm{T}_{1}$ & 4.0 & 0.1 & 4.1 & 9.3 & 80.2 & 78.2 & 57.8 & 1.6 & 0.4 & 1.1 & 0.1 & 27.7 & 223.9 \\
\hline $\mathrm{T}_{2}$ & 102.0 & 48.8 & 150.8 & 64.8 & 152.6 & 103.0 & 108.5 & 1.7 & 0.5 & 0.7 & 0.3 & 265.0 & 538.8 \\
\hline \multirow[t]{2}{*}{$\mathrm{T}_{3}$} & 200.0 & 97.4 & 297.5 & 120.3 & 224.9 & 127.8 & 159.3 & 1.7 & 0.6 & 0.4 & 0.5 & 502.3 & 853.8 \\
\hline & \multicolumn{13}{|c|}{2017 cycle } \\
\hline Treatments & $\mathrm{N}-\mathrm{NH}_{4}^{+}$ & $\mathrm{N}^{-\mathrm{NO}_{3}}$ & N Total & $\mathrm{P}$ & K & $\mathrm{Ca}$ & $\mathrm{Mg}$ & $\mathrm{Fe}$ & $\mathrm{Mn}$ & $\mathrm{Zn}$ & $\mathrm{Cu}$ & $\mathrm{Na}$ & $\mathrm{Cl}$ \\
\hline $\mathrm{T}_{1}$ & 4.4 & 0.2 & 4.6 & 10.4 & 89.6 & 87.4 & 64.5 & 1.8 & 0.5 & 1.2 & 0.2 & 31.0 & 250.0 \\
\hline $\mathrm{T}_{2}$ & 115.8 & 55.4 & 171.3 & 73.4 & 171.8 & 115.5 & 122.2 & 1.9 & 0.6 & 0.8 & 0.4 & 300.6 & 608.0 \\
\hline $\mathrm{T}_{3}$ & 227.2 & 110.7 & 337.9 & 136.5 & 254.1 & 143.6 & 179.9 & 1.9 & 0.6 & 0.4 & 0.6 & 570.2 & 965.9 \\
\hline
\end{tabular}

$\mathrm{NH}_{4}{ }^{+}$-N: Ammoniacal nitrogen; $\mathrm{NO}_{3}{ }^{-} \mathrm{N}$ : Nitric nitrogen; Total-N: Total nitrogen; P: Phosphorus; K: Potassium; Ca: Calcium; Mg: Magnesium; Fe: Iron; Mn: Manganese; Zn: Zinc; Cu: Copper; Na: Sodium; Cl: Chlorine.

Table 7

Percentages of nutrients supplied in relation to the quantities required in the two cultivation cycles

\begin{tabular}{cccccccccc}
\hline \multicolumn{7}{c}{ Nutrient percentages relative to crop requirement (2016 cycle) } \\
\hline Treatments & $\mathrm{N}$ & $\mathrm{P}$ & $\mathrm{K}$ & $\mathrm{Ca}$ & $\mathrm{Mg}$ & $\mathrm{Fe}$ & $\mathrm{Mn}$ & $\mathrm{Zn}$ & $\mathrm{Cu}$ \\
$\mathrm{T}_{1}$ & 1 & 10 & 28 & 55 & 136 & 52 & 118 & 497 & 68 \\
$\mathrm{~T}_{2}$ & 46 & 68 & 53 & 73 & 255 & 53 & 137 & 341 & 163 \\
$\mathrm{~T}_{3}$ & 90 & 126 & 77 & 90 & 375 & 54 & 155 & 185 & 258 \\
\hline \multicolumn{7}{c}{ Nutrient percentages relative to crop requirement (2017 cycle) } \\
\hline Treatments & $\mathrm{N}$ & $\mathrm{P}$ & $\mathrm{K}$ & $\mathrm{Ca}$ & $\mathrm{Mg}$ & $\mathrm{Fe}$ & $\mathrm{Mn}$ & $\mathrm{Zn}$ & $\mathrm{Cu}$ \\
$\mathrm{T}_{1}$ & 1 & 11 & 31 & 62 & 152 & 58 & 132 & 556 & 75 \\
$\mathrm{~T}_{2}$ & 52 & 77 & 59 & 81 & 288 & 59 & 153 & 378 & 184 \\
$\mathrm{~T}_{3}$ & 102 & 143 & 88 & 101 & 423 & 60 & 174 & 201 & 292 \\
\hline
\end{tabular}

N: Nitrogen; P: Phosphorus; K: Potassium; Ca: Calcium; Mg: Magnesium; Fe: Iron; Mn: Manganese; Zn: Zinc; Cu: Copper. 
In the literature, there are several studies indicating the potential of TDE in providing significant amounts of organic matter and nutrients such as $\mathrm{P}, \mathrm{K}, \mathrm{Ca}$ and $\mathrm{Mg}$ to the soil, especially in soils with more clayey texture (Damasceno, Andrade, Gheyi, Dias, \& Silva, 2011; Fortes et al., 2013; Alves, Santos, Kondo, Araújo, \& Oliveira, 2018 ), and it may even meet $100 \%$ of the nutritional requirements of the cotton crop, thus replacing conventional fertilization, as reported by Sousa et al. (2012). Thus, the use of treated domestic effluents plays a fundamental role in the planning and sustainable management of water resources, as it allows the sources of good quality water to be used for public supply and other priority uses (Lunardi \& Rabaiolli, 2013). According to Costa et al. (2014), the use of effluents in agriculture constitute an alternative for the control of pollution in the water-soil-atmosphere system, supplying and recycling nutrients that are essential for crops and consequent increase in agricultural production. However, it should be pointed out that the amount of nutrients present in domestic effluents is variable, so it is necessary to conduct studies of each condition under which the effluent is obtained.

\section{Growth evaluation}

The different percentages of TDE applied through fertigation caused significant differences $(\mathrm{p}<0.05)$ in the variables $\mathrm{AGR}_{\mathrm{TB}}$ (absolute growth rate of total shoot dry biomass) and $\mathrm{RGR}_{\mathrm{TB}}$ (relative growth rate of total biomass) of herbaceous cotton (BRS 335), in two cultivation cycles, in the presence and absence of phosphate fertilization (Table 8).

\section{Table 8}

Summary of analysis of variance for the absolute growth rate of total biomass (AGR (AB $_{\text {) }}$ and relative growth rate of total biomass $\left(\mathrm{RGR}_{\mathrm{TB}}\right)$ of cotton fertigated with different percentages of treated domestic effluent in two cultivation cycles

\begin{tabular}{|c|c|c|c|c|c|}
\hline \multirow{3}{*}{ SV } & \multirow{3}{*}{$\mathrm{DF}$} & \multirow{2}{*}{\multicolumn{2}{|c|}{$\begin{array}{c}\operatorname{Pr}>\mathrm{Fc} \\
2016 \text { cycle }\end{array}$}} & $\operatorname{Pr}>\mathrm{Fc}$ & $\mathrm{Pr}>\mathrm{Fc}$ \\
\hline & & & & \multicolumn{2}{|c|}{2017 cycle } \\
\hline & & $\mathrm{AGR}_{\mathrm{TB}}$ & $\mathrm{RGR}_{\mathrm{TB}}$ & $\mathrm{AGR}_{\mathrm{TB}}$ & $\mathrm{RGR}_{\mathrm{TB}}$ \\
\hline Block & 5 & $0.86^{\mathrm{ns}}$ & $0.83^{\text {ns }}$ & $0.61^{\mathrm{ns}}$ & $0.41^{\mathrm{ns}}$ \\
\hline Treatment (TRAT) & 2 & $0.00^{*}$ & $0.00 *$ & $0.00 *$ & $0.00 *$ \\
\hline Error 1 & 10 & & & & \\
\hline Management (MA) & 1 & $0.00^{*}$ & $0.03 *$ & $0.09^{\mathrm{ns}}$ & $0.24^{\mathrm{ns}}$ \\
\hline TRAT*MA & 2 & $0.70^{\mathrm{ns}}$ & $0.50^{\mathrm{ns}}$ & $0.65^{\mathrm{ns}}$ & $0.87^{\mathrm{ns}}$ \\
\hline Error 2 & 15 & & & & \\
\hline Time & 5 & $0.00^{*}$ & $0.00 *$ & $0.00 *$ & $0.00 *$ \\
\hline TRAT*time & 10 & $0.00^{*}$ & $0.00^{*}$ & $0.00^{*}$ & $0.00 *$ \\
\hline MA*tempo & 5 & $0.78^{\mathrm{ns}}$ & $0.85^{\mathrm{ns}}$ & $0.24^{\mathrm{ns}}$ & $0.00 *$ \\
\hline TRAT*MA*time & 10 & $0.80^{\mathrm{ns}}$ & $0.73^{\mathrm{ns}}$ & $0.47^{\mathrm{ns}}$ & $0.16^{\mathrm{ns}}$ \\
\hline Error 3 & 150 & & & & \\
\hline CV $1(\%)$ & & 60.9 & 7.2 & 68.85 & 4.5 \\
\hline CV $2(\%)$ & & 23.3 & 3.3 & 38.6 & 2.6 \\
\hline CV $3(\%)$ & & 68.6 & 21.0 & 76.8 & 15.3 \\
\hline
\end{tabular}

SV: Sources of variation; DF: Degrees of freedom; CV: Coefficient of variation; Values of $\operatorname{Pr}>\mathrm{Fc}<0.05$ and $\geq 0.01$ indicate significance at $5 \%$ probability level, and values of $\operatorname{Pr}>\mathrm{Fc}<0.01$ indicate significance at $1 \%$ probability level; ns: not significant. 
Fertigation with TDE led to higher values of $\mathrm{AGR}_{\mathrm{TB}}$ from $36 \mathrm{DAG}$ (Table 9), and this superiority is attributed to the high contents of nutrients and organic matter present in the effluent (Table 5). This result occurred starting from 36 DAG because fertigation started at $10 \mathrm{DAG}$, so there was not enough time for the nutritional benefits promoted by the use of treated effluent to take effect until 35 DAG. There is no difference in the growth of plants fertigated with $\mathrm{T}_{2}$ and $\mathrm{T}_{3}$ in the different evaluation periods, indicating that, even diluted $\left(\mathrm{T}_{2}\right)$, the TDE is a satisfactory source of water and nutrients for cotton growth (Table 9). Increases in cotton growth when irrigated with TDE have also been reported by Sousa et al. (2012) and Andrade et al. (2013), thus corroborating the present study and reinforcing the fertilizer power of this source of wastewater.

The maximum $\mathrm{AGR}_{\mathrm{TB}}$ occurred in the period between 50 and 64 DAG in the first cycle, in all treatments, being superior in treatments that received irrigation with TDE (at least 3.96 times higher), in which the plants showed higher dry matter content (higher photosynthetic efficiency) compared to those that did not receive TDE $\left(\mathrm{T}_{1}\right)$. In the second cycle, the highest $\mathrm{AGR}_{\mathrm{TB}}$ occurred in the period between 56 and $70 \mathrm{DAG}$ for treatment $\mathrm{T}_{1}$ (control, $0.7385 \mathrm{~g} \cdot \mathrm{day}^{-1}$ ) and between 70 and $84 \mathrm{DAG}$ for the treatments that received TDE (3.1739 $\mathrm{g} \cdot$ day $^{-1}$ and $3.8972 \mathrm{~g} \cdot$ day $^{-1}$ for $\mathrm{T}_{2}$ and $\mathrm{T}_{3}$, respectively), showing an increase in the vegetative growth period. This can be attributed to a greater amount of $\mathrm{N}$ applied via irrigation with TDE in the second cultivation cycle (Table 5), because $\mathrm{N}$ stimulates vegetative growth and delays flowering (Lima et al., 2006; Rigon, Brito, Capuani, Beltrão, \& Silva, 2011). Results similar to those obtained in this study were reported by Silva, Lima, Silva, Sofiatti and Pereira (2013), who observed, in the treatments irrigated with supply water, that the more accentuated vegetative growth stage was concentrated in the first 50 days after emergence; on the other hand, when irrigation was performed using treated domestic effluent, this stage was longer.

\section{Table 9}

Mean values for the absolute growth rate of total biomass (AGR ${ }_{T B}$ ) of herbaceous cotton (BRS 335) fertigated with different percentages of treated domestic effluent (TDE), in two cultivation cycles

\begin{tabular}{|c|c|c|c|c|c|c|}
\hline \multirow{3}{*}{ Treatments } & \multicolumn{6}{|c|}{$\operatorname{AGR}_{\mathrm{TB}}(2016$ cycle $)$} \\
\hline & \multicolumn{6}{|c|}{ Evaluation seasons (DAG) } \\
\hline & 22 & 36 & 50 & 64 & 78 & 92 \\
\hline & \multicolumn{6}{|c|}{ 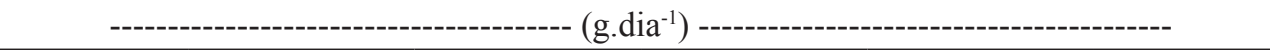 } \\
\hline $\mathrm{T}_{1}$ & $0.0512 \mathrm{~A}$ & $0.2156 \mathrm{~B}$ & $0.4659 \mathrm{~B}$ & $0.8559 \mathrm{~B}$ & $0.6019 \mathrm{~A}$ & $1.0126 \mathrm{~A}$ \\
\hline $\mathrm{T}_{2}$ & $0.1339 \mathrm{~A}$ & $0.6851 \mathrm{AB}$ & $1.3565 \mathrm{~A}$ & $3.7001 \mathrm{~A}$ & $1.2039 \mathrm{~A}$ & $0.7538 \mathrm{~A}$ \\
\hline $\mathrm{T}_{3}$ & $0.1832 \mathrm{~A}$ & $0.9984 \mathrm{~A}$ & $1.6676 \mathrm{~A}$ & $3.3931 \mathrm{~A}$ & $1.1564 \mathrm{~A}$ & $0.8967 \mathrm{~A}$ \\
\hline LSD & 0.7115 & & & & & \\
\hline \multirow{4}{*}{ Treatments } & \multicolumn{6}{|c|}{$\operatorname{AGR}_{\mathrm{TB}}(2017$ cycle $)$} \\
\hline & \multicolumn{6}{|c|}{ Evaluation seasons (DAG) } \\
\hline & 16 & 28 & 42 & 56 & 70 & 84 \\
\hline & \multicolumn{6}{|c|}{----- (g.dia } \\
\hline $\mathrm{T}_{1}$ & $0.0232 \mathrm{~A}$ & $0.0770 \mathrm{~A}$ & $0.2550 \mathrm{~B}$ & $0.4084 \mathrm{~B}$ & $0.7385 \mathrm{~B}$ & $0.6448 \mathrm{~B}$ \\
\hline $\mathrm{T}_{2}$ & $0.0344 \mathrm{~A}$ & $0.3022 \mathrm{~A}$ & $0.9695 \mathrm{AB}$ & $2.3901 \mathrm{~A}$ & $2.8734 \mathrm{~A}$ & $3.1739 \mathrm{~A}$ \\
\hline $\mathrm{T}_{3}$ & $0.0410 \mathrm{~A}$ & $0.4404 \mathrm{~A}$ & $1.5606 \mathrm{~A}$ & $1.6918 \mathrm{~A}$ & $2.7014 \mathrm{~A}$ & $3.8972 \mathrm{~A}$ \\
\hline LSD & 0.9157 & & & & & \\
\hline
\end{tabular}

Means followed by the same letter in the column do not differ statistically at the $5 \%$ significance level by Tukey test. $\mathrm{DAG}=$ Days after germination; $\mathrm{LSD}=$ Least significant difference. 
For $\mathrm{RGR}_{\mathrm{TB}}$, there was significant variation only at the beginning of the two cultivation cycles, with higher values in treatments fertigated with TDE (Table 10). This behavior is considered normal, because $\mathrm{RGR}_{\mathrm{TB}}$ is a result of the previous growth of the plant. Such continuous reduction of $\mathrm{RGR}_{\mathrm{TB}}$ can be explained by the growth of the plant, which implies greater expenditure with the maintenance of the structures, resulting in greater maintenance respiration. Another factor that contributed to the reduction in $\mathrm{RGR}_{\mathrm{TB}}$ was self-shading, whose importance increases with plant age (Freitas et al., 2006; Coelho, Freitas, Cunha, Dombroski, \& Santana, 2013). In addition, in the final stage of the crop, there is a reduction in $\mathrm{RGR}_{\mathrm{TB}}$ due to the gradual increase of non-assimilatory tissues (Alvarez, Crusciol, \& Nascente, 2012).

No significant effect was observed in the interaction between fertigation with TDE and phosphate fertilization management (presence and absence of phosphorus fertilizer at pre-planting) for the variables $A G R_{\mathrm{TB}}$ and $\mathrm{RGR}_{\mathrm{TB}}$. In the treatment with only public supply water $\left(\mathrm{T}_{1}\right)$, there was also no significant response to phosphorus application. This demonstrates that the soil already contained the amount of phosphorus necessary for the development of the crop (Table 1).

\section{Table 10}

Mean values for the relative growth rate of total biomass (RGR ${ }_{\mathrm{TB}}$ ) of herbaceous cotton (BRS 335) fertigated with different percentages of treated domestic effluent (TDE), in two cultivation cycles

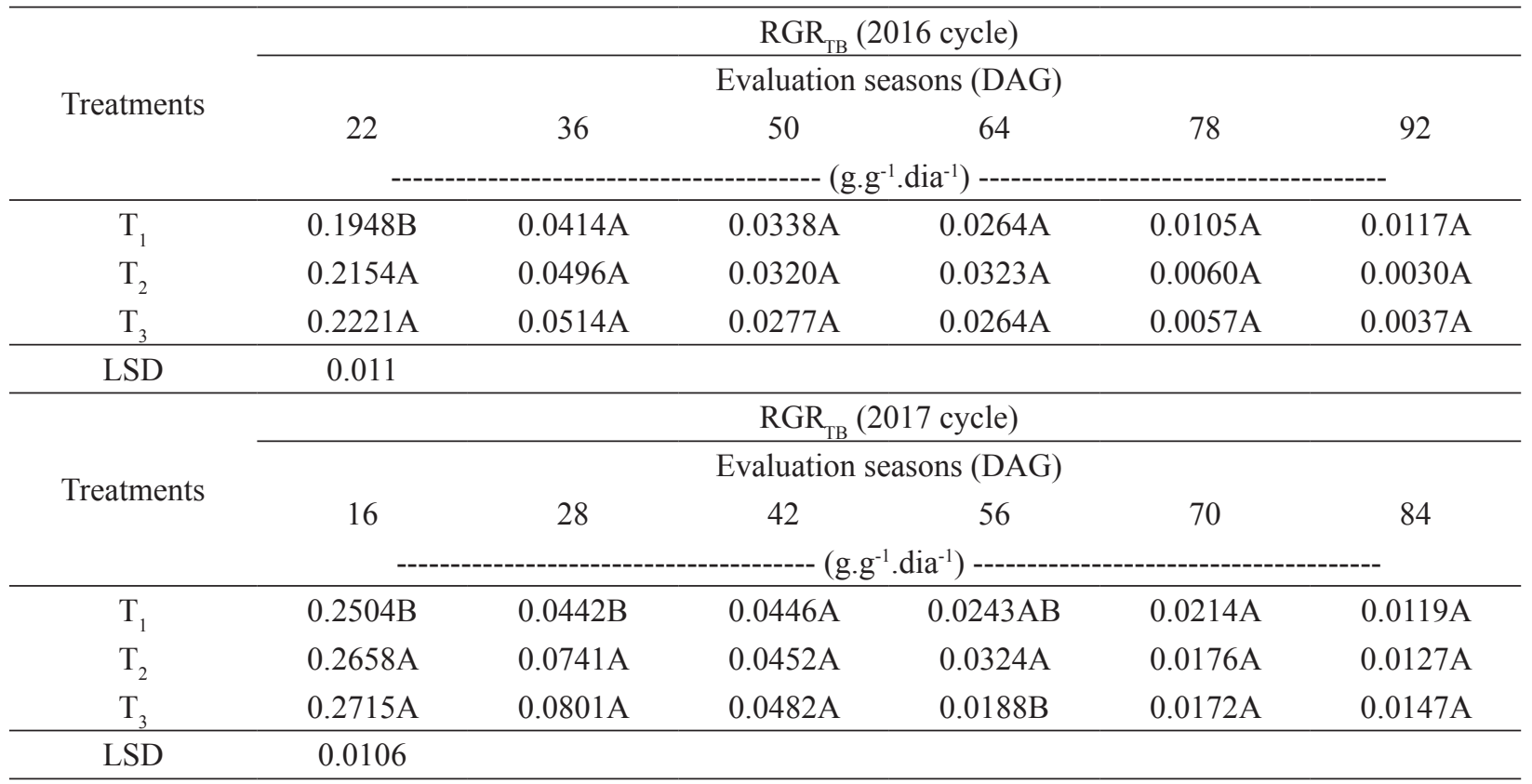

Means followed by the same letter in the column do not differ statistically at $5 \%$ significance level by Tukey test. $\mathrm{DAG}=$ Days after germination; $\mathrm{LSD}=$ Least significant difference . 
Phosphorus management alone caused significant variation in the first cultivation cycle (2016), and the presence of phosphorus promoted better results for $\mathrm{AGR}_{\mathrm{TB}}$ and $\mathrm{RGR}_{\mathrm{TB}}$ (Figure 1). In the second cultivation cycle (2017), the residual effect of the previous cultivation, combined with the nutrients added via fertigation with TDE, met the requirements of nutrients, including phosphorus, for the crop to obtain maximum yield. This residual effect of irrigation with TDE in cotton has already been observed by other authors, such as Silva et al. (2013), who cultivated cotton in succession with sesame and concluded that, compared to irrigation with public supply water, the application of TDE intensifies the vegetative growth of cotton.
(A)

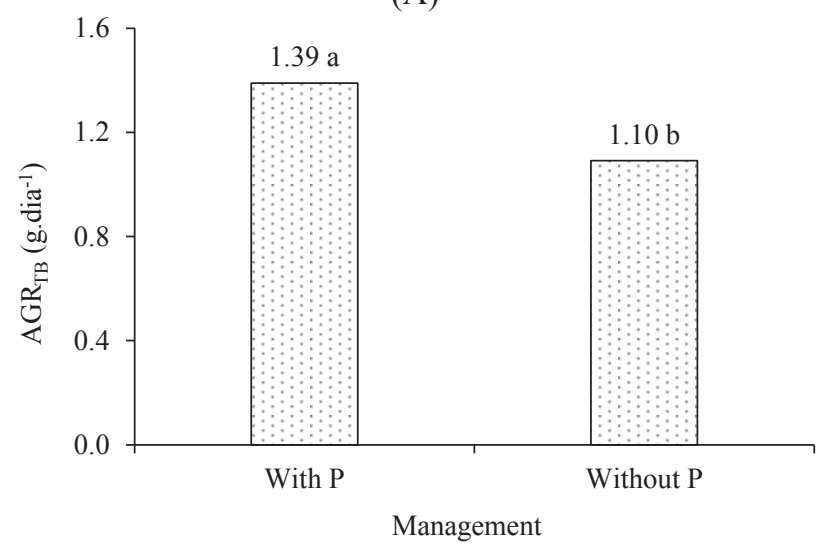

(B)

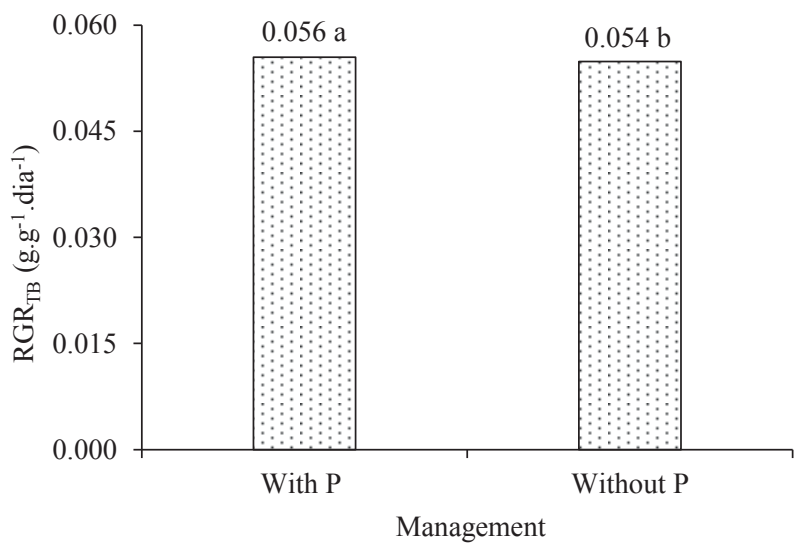

Figure 1. Mean variation of the absolute growth rate of total biomass $\left(\mathrm{AGR}_{\mathrm{TB}}\right)(\mathrm{A})$, and relative growth rate of total biomass $\left(\mathrm{RGR}_{\mathrm{TB}}\right)(\mathrm{B})$, of herbaceous cotton (BRS 335), under different pre-planting management regimes (with and without phosphate fertilization at pre-planting) in the cultivation cycle of 2016

\section{Conclusions}

Irrigation with treated domestic sewage effluent does not hamper herbaceous cotton development and this effluent can be used as a source of water and nutrients;

The use of $50 \%$ treated domestic effluent in substitution for public supply water adds amounts of nutrients to the soil that are greater than the cotton crop requirements for $\mathrm{Mg}, \mathrm{Mn}, \mathrm{Zn}$ and $\mathrm{Cu} ; 50 \%$ greater than its needs for $\mathrm{P}, \mathrm{K}, \mathrm{Ca}$ and $\mathrm{Fe}$; and equal to or $45 \%$ higher than the nutritional requirements for $\mathrm{N}$ in the two cultivation cycles, with a proportional increase in the supply of nutrients when $100 \%$ treated domestic effluent is used in irrigation;

Phosphate fertilization at pre-planting had effect on the growth of cotton plants only in the first cultivation cycle;
Fertigation with domestic effluent caused a residual effect on the phosphorus supply to the plants in the second cultivation cycle.

\section{Referências}

Allen, R. G., Pereira, L. S., Raes, D., \& Smith, M. (2006). Evapotraspiración del cultivo. Utah State University. Guías para la determinación de los requerimientos de água de los cultivos. Rome: FAO.

Alvarez, R. C. F., Crusciol, C. A. C., \& Nascente, A. S. (2012). Análise de crescimento e produtividade de cultivares de arroz de terras altas dos tipos tradicional, intermediário e moderno. Pesquisa Agropecuária Tropical, 42(4), 397-412. doi: 10.1590/S198340632012000400008

Alves, P. F. S., Santos, S. R., Kondo, M. K., Araújo, E. D., \& Oliveira, P. M. (2018). Fertirrigação do milho com água residuária sanitária tratada: crescimento e produção. Engenharia Sanitária e Ambiental, 23(5), 833-839. doi: 10.1590/s1413-41522018136152 
Andrade, J., Fo , Sousa, O. N., Neto, Dias, N. S., Rebouças, J. L. R., Nascimento, I. B., Medeiros, J. F., \& Cosme, C. R. (2013). Atributos químicos de solo fertirrigado com água residuária no semiárido brasileiro. Irriga, 18(4), 661-674. doi: 10.15809/ irriga.2013v18n4p661

Bertoncini, E. I. (2008). Tratamento de efluentes e reúso da água no meio agrícola. Revista Tecnologia \& Inovação Agropecuária, 1(1), 152-169.

Coelho, M. E. H., Freitas, F. C. L., Cunha, J. L. X. L., Dombroski, J. D., \& Santana, F. A. O. (2013). Interferência de plantas daninhas no crescimento do pimentão nos sistemas de plantio direto e convencional. Revista Caatinga, 26(4), 19-30.

Condé, M. S., Homem, B. G. C., Almeida, O. B., Neto, \& Santiago, A. M. F. (2012). Influência da aplicação de águas residuárias de criatórios de animais no solo: atributos químicos e físicos. Revista Brasileira de Agropecuária Sustentável, 2(1), 99-106.

Costa, Z. V. B., Gurgel, M. T., Costa, L. R., Alves, S. M. C., Ferreira, M., Neto, \& Batista, R. O. (2014). Efeito da aplicação de esgoto doméstico primário na produção de milho no assentamento Milagres (Apodi-RN). Revista Ambiente \& Água, 9(4), 737 751. doi: 10.4136/ambi-agua. 1417

Cunha, A. H. N., Oliveira, T. H., Ferreira, R. B., Milhardes, A. L. M., \& Silva, S. M. C. (2011). O reúso de água no Brasil: a importância da reutilização de água no país. Enciclopédia Biosfera, 7(13), 1225-1248.

Damasceno, L. M. O., Andrade, A. S., Jr., Gheyi, H. R., Dias, N. S., \& Silva, C. O. (2011). Composição nutricional foliar da gérbera irrigada com efluente doméstico tratado. Revista Caatinga, 24(2), 121128.

Diniz, M. T. M., \& Pereira, V. H. C. (2015). Climatologia do estado do Rio Grande do Norte, Brasil: sistemas atmosféricos atuantes e mapeamento de tipos de clima. Boletim Goiano de Geografia, 35(3), 488-506.

Empresa Brasileira de Pesquisa Agropecuária. Manual de métodos de análise do solo. (2011). Rio de Janeiro: EMBRAPA Solos.

Fernandes, P. D. Análise de crescimento e desenvolvimento vegetal. (2002). Campina Grande: UFPB, DEAg.

Ferreira,D.F.(2011). Sisvar: a computer statistical analysis system. Ciência e Agrotecnologia, 35(6), 1039-1042. doi: 10.1590/S1413-70542011000600001

Fortes, P., Neto, Veiga, P. G. A., Fortes, N. L. P., Targa, M. S., Gadioli, J. L., \& Peixoto, P. M. H. (2013). Alterações químicas do solo e produção de aveia fertilizada com água residuária do tratamento de esgoto sanitário. Revista Ambiente \& Água, 8(4), 7183. doi: 10.4136/ambi-agua. 1368

Freitas, R. S., Tomaz, M. A., Ferreira, L. R., Berger, P. G., Pereira, C. J., \& Cecon, P. R. V. (2006). Growth of cotton treated with trifloxysulfuron-sodium. Planta Daninha, 24(1), 123-129. doi: 10.1590/S010083582006000100016

Hao, F., Li, J., Wang, Z., \& Li, Y. (2017). Effect of ions on clogging and biofilm formation in drip emitters applying secondary sewage effluent. Irrigation and Drainage, 66(5), 687-698. doi: 10.1002/ird.2141

Holanda, J. S., Dantas, J. A., Medeiros, A. A., Ferreira, M., Neto, Medeiros, J. F., \& Guedes, F. X. (2017). Indicadores para a adubação de culturas em solos do Rio Grande do Norte. Natal: EMPARN.

Lima, M. M., Azevedo, C. A. V., Beltrão, N. E. M., Dantas, J., Neto, Gonçalves, C. B., \& Santos, C. G. F. (2006). Nitrogênio e promotor de crescimento: efeitos no crescimento e desenvolvimento do algodão colorido verde. Revista Brasileira de Engenharia Agrícola e Ambiental, 10(3), 624-628. doi: 10.1590/ S1415-43662006000300013

Lunardi, J., \& Rabaiolli, J. A. (2013). Valorização e preservação dos recursos hídricos na busca pelo desenvolvimento rural sustentável. Revista OKARA: Geografia em Debate, 7(1), 44-62.

Ribeiro, A. C., Guimarães, P. T. G., \& Alvarez, V. H. (Eds.). (1999). Recomendações para o uso de corretivos e fertilizantes em Minas Gerais. $5^{\mathrm{a}}$ Aproximação. Viçosa: Comissão de Fertilidade do Estado de Minas Gerais.

Ribeiro, M. C. F., Rocha, F. A., Santos, A. C., Silva, J. O., Peixoto, M. F. S. P., \& Paz, V. P. S. (2012). Crescimento e produtividade da mamoneira irrigada com diferentes diluições de esgoto doméstico tratado. Revista Brasileira de Engenharia Agrícola e Ambiental, 16(6), 639-646. doi: 10.1590/S141543662012000600008

Rice, E. W., Baird, R. B., \& Clesceri, A. D. (2012). Standard methods for the examination of water and wastewater. Washington: APHA, AWWA, WPCR.

Rigon, J. P. G., Brito, J. F., Neto, Capuani, S., Beltrão, N. E. M., \& Silva, F. V. F. (2011). Utilização de nitrogênio e níquel durante o crescimento do algodão. Enciclopédia Biosfera, 7(13), 1019-1026.

Santos, H. G., Jacomine, P. K. T., Anjos, L. H. C., Oliveira, V. A., Lumbreras, J. F., Coelho, M. R., ... Oliveira, J. B. (2013). Sistema brasileiro de classificação de solos. Brasília: EMBRAPA. 
Silva, L. P., Silva, M. M., Correa, M. M., Souza, F. C. D., \& Silva, E. F. F. (2011). Desempenho de gotejadores autocompensantes com diferentes efluentes de esgoto doméstico. Revista Brasileira de Engenharia Agrícola e Ambiental, 16(6), 480-486. doi: 10.1590/ S1415-43662012000500003

Silva, L. V. B. D., Lima, V. L. A., Silva, V. N. B., Sofiatti, V., \& Pereira, T. L. P. (2013). Torta de mamona residual e irrigação com efluente sobre crescimento e produção de algodoeiro herbáceo. Revista Brasileira de Engenharia Agrícola e Ambiental, 17(12), 12641270. doi: 10.1590/S1415-43662013001200003
Sousa, O. N., Neto, Andrade, J., Fo , Dias , N. S., Rebouças, J. R. L., Oliveira, F. R. A., \& Diniz, A. A. (2012). Fertirrigação do algodoeiro utilizando efluente de esgoto doméstico tratado. Brasileira de Engenharia Agrícola e Ambiental, 16(2), 200-208. doi: 10.1590/ S1415-43662012000200011 
